\section{US analysis incomplete}

\section{Washington}

EFFORTS in the United States to estimate Chernobyl reactor accident were hampered last week by the lack of detailed information on the radionuclides released. But researchers at Lawrence Livermore (LL) National Laboratory now believe that most of an assumed core inventory of 80 million curies of iodine-131 and 6 million curies of caesium-137 was released during the disaster, a "mammoth emission" in the words of Joseph Knox, head of LL's atmospheric release advisory centre. The amount of iodine-131 released during the US Three Mile Island reactor accident was, by comparison, a mere 15 curies.

A substantial proportion, perhaps as much as half of the total emitted, appears to have been borne with the initial explosion to a height of 20,000 feet or more and then transported eastwards, according to Knox.

The other half of the activity release was injected at low altitude and was initially blown north-west, according to Knox. One of the highest atmospheric activities recorded outside the Eastern bloc was in Stockholm, where a level of 5,130 picocuries of iodine-131 per cubic metre of air was found.

Monitoring data are being provided by many friendly and neutral countries and by US embassies around the world, as well as by the domestic monitoring network. The inventory of nuclides appears to be much as would be expected from a civilian power reactor: besides iodine and caesium, tellurium, ruthenium and some technetium are found. But the US interagency task force collating data on the accident is puzzled by an almost total absence of the expected strontium-90.

Knox's group, with its normal staff of 22 supplemented because of the Chernobyl work, has been working more than 12 hours per day since the accident to model the atmospheric consequences of the release with supercomputers.

Meteorological data for the simulation are being supplied by the US Air Force's Global Weather Center. Preliminary simulations suggest that adult thyroid accident would have surpassed 1 rem over an $85,000 \mathrm{~km}^{2}$ swathe of the Soviet Union, extending into northeastern Poland.

It will be almost impossible to get a clear picture of the much higher radiation doses and expected prompt radiation deaths close to the plant without Soviet data on activity levels and evacuation timetables.

There is equal uncertainty about the circumstances that caused the accident. The International Atomic Energy Agency (IAEA) team visiting the area has reported that the reactor was operating at the long-term consequences of the doses during the two days following the low power for scheduled maintenance when the accident occurred.

Frank Clikeman, professor of nuclear engineering at the University of Indiana, observes that the $\mathrm{RBMK}-1000$ reactor is likely to have a positive power coefficient in a loss of coolant accident, meaning that the rate of power generation in the reactor would increase as its temperature went up; this is because the graphite moderator, unlike water, does not expand significantly as it is heated. Attempts to dered by a loss of electrical power.

Despite earlier fears, the possibility of a complete meltdown of the reactor fuel and its sinking through the floor of the reactor to contaminate ground water seemed to be receding late last week.

The nuclear power industry in the United States is stressing that plant design safety standards in the United States are much higher than in the Soviet Union; in particular, the Soviet reactor had no containment building. But it is nevertheless inevitable that heightened concern over nuclear safety will delay licensing of the 20 rescue the situation may have been hin- or more nuclear plants expecting approval in the next few years.

Congress has already postponed action on renewal of the Price Anderson Nuclear Insurance Act and procedures for licensing standardized reactor designs pending a fuller evaluation of the Cherynobyl accident. The Secretary of Energy, John Herrington, has ordered a special safety review of the only US reactor with appreciable similarities to Chernobyl, the "N reactor" at Richland, Washington state, which produces nuclear material for bombs. This reactor is also graphitemoderated and has no containment building.

There are other US reactors that lack containment buildings at the Department of Energy's Savannah River site in South Carolina, also a weapons site.

Some US scientists have made informal proposals for collaborative studies with overseas scientists to Professor Walter Rosenblith, foreign secretary of the US National Academy of Sciences, but as yet the academy (which recently signed a scientific collaboration agreement with the Soviet Union) has made no formal proposals.

\section{Where does the blame lie?}

THREE Ukrainian party officials have been | called on people not to panic.

disciplined in connection with the Chernobyl disaster. According to the Soviet newspaper Pravda on 12 May, one was expelled from the party for indifference and shirking his duty to look after refugees, a second was severely reprimanded for the same offences, and the third was reprimanded for failing to give "timely and accurate" information on the disaster.

The dismissals came after several days of veiled admissions by Soviet officials that there had been slackness and confusion in the disaster area. Thus eulogies of the emergency teams fighting the reactor fire and building defences beneath it in case of meltdown were coupled with criticism of the few who had failed to show the appropriate heroism and steadfastness in what was described as the "front line".

Western critics have attacked the Soviet treatment of the disaster for the failure to provide sufficient information both to their own population and to other countries liable to be affected by the radioactive cloud and for their failure to evacuate the local population in good time. A careful reading of the Soviet press over the past week suggests that, between 2 and 7 May, Moscow gradually became aware that the Western allegations, which it had denied in all good faith, had, in fact, some substance.

Evacuation had indeed been delayed at Chernobyl itself for a whole week and the radiation hazard was far greater than announced. On $8 \mathrm{May}$, the Soviet media gave accounts of long queues for any available train out of the city. Pravda even
According to this reading of the situation, for about 10 days after the accident, officials in Moscow were desperately trying to tell the world the truth as they knew it, but all the time were inadvertently relaying misinformation. The blame for this has been fixed on the officials on the spot, with possible further reprimands and dismissals gradually making their way up the Ukrainian party and state hierarchy. The Ukrainian and Byelorussian republics have, formally speaking, the greatest degree of autonomy of all the constituent republics of the Soviet Union.

Although the Soviet power industry, and the nuclear programme in particular, are organized on an All-Union basis, responsibility at Chernobyl, at least for the post-disaster chaos, has been laid by Moscow at the door of the Ukrainians.

But Moscow cannot eschew all responsibility. The original claim was that 50,000 people had been evacuated from the vicinity of the power station on the afternoon of Sunday, 27 April. Even if plans for evacuation had been made when the first signs of trouble developed on Friday, 25 April, the logistics of the operation must have made the claim somewhat improbable. Yet nobody seems to have thought to verify the claim. If, as is now widely believed, it was the visit of Prime Minister Nikolai Ryzhkov to the area at the beginning of May that revealed to the central authorities that the town of Chernobyl had not been evacuated, it must have been Moscow, and not Kiev, that suppressed this fact for a further five days. Vera Rich 